\section{EMBRYRIDDLE}

Aeronautical University

SCHOLARLY COMMONS
Journal of Aviation/Aerospace

Education \& Research

Volume 8

Number 2 JAAER Winter 1998

Article 1

Winter 1998

\title{
A Pioneering University-Airline Flight Internship Program: A Follow-Up Study of Intern Participants
}

David A. NewMyer Ph.D.

newmyer@siu.edu

Jose R. Ruiz

D. Scott Worrells

worrelld@erau.edu

Follow this and additional works at: https://commons.erau.edu/jaaer

\section{Scholarly Commons Citation}

NewMyer, D. A., Ruiz, J. R., \& Worrells, D. S. (1998). A Pioneering University-Airline Flight Internship Program: A Follow-Up Study of Intern Participants. Journal of Aviation/Aerospace Education \& Research, 8(2). https://doi.org/10.15394/jaaer.1998.1226

This Article is brought to you for free and open access by the Journals at Scholarly Commons. It has been accepted for inclusion in Journal of Aviation/Aerospace Education \& Research by an authorized administrator of Scholarly Commons. For more information, please contact commons@erau.edu. 


\title{
A PIONEERING UNIVERSITY-AIRLINE FLIGHT INTERNSHIP PROGRAM A FOLLOW-UP STUDY OF INTERN PARTICIPANTS
}

\author{
David A. NewMyer, Ph.D., Jose R. Ruiz, D. Scott Worrells
}

This article presents the results of a follow-up survey administered to 110 former university interns who served a semester long internship in the flight operations department at United Airlines. The intent of the survey was to discover if the purposes of the internship had been fulfilled. Also, the survey gathered information on the characteristics of the internship participants in terms of their current employment in the aviation industry with the goal of discovering, among other things, how many of the interns were ultimately hired by United Airlines. A total of 78 of the 110 interns surveyed returned a completed survey. The results indicated that over half (41 of 78) of the respondents had, indeed, been hired in a pilot position by a major airline with the vast majority of these ( 36 or 41 hired by a major) hired by United Airlines. Of those not hired by United Airlines, only two are no longer in aviation while the rest are employed at other major airlines, regional airlines, corporate flight departments or in some part of general aviation such as flight instruction.

\section{INTRODUCTION}

In July 1987, Southern Illinois University, Carbondale (SIUC) and United Airlines joined together in one of the country's first major airline-university internship agreements. According to the original agreement, the purposes of the internship program were to:
1. Develop additional resources for high quality flight officer candidates.
2. Improve the supply of qualified flight officer candidates.
3. Increase the number of qualified minority and female flight officer candidates.
4. Take advantage of the college and university system as a resource for the pilot of the future. (Spencer, 1988)

More than ten years have passed since the signing of the internship agreement. Has the internship program realized its original objectives? What are the overall characteristics of the students who participated in the United Airlines-SIUC internship program? What are the characteristics of interns hired at United Airlines? What are the characteristics of interns not hired at United Airlines? This paper will examine the impact that the United Airlines-SIUC internship agreement has had on SIUC aviation students who have participated in the program.

\section{DESCRIPTION OF THE UNITED AIRLINES-SIUC INTERNSHIP PROGRAM}

The United Airlines-SIUC internship program provides airline specific learning experiences for SIUC aviation students every academic semester (Spring, Summer, and Fall). It exposes the student to two levels of internship experience. The first level of internship is the "United Airlines Off Campus Study Program," or more commonly known as the "short internship." The selection process for the short internship is highly competitive.

To compete for the United internship students must possess the following qualifications:

1. $\mathrm{Be}$ an active SIUC Aviation Management (AVM)/Aviation Flight (AF) major who has completed flight requirements for the SIUC Associate of Applied Science (A.A.S.) Degree in Aviation Flight at SIUC's FAR Part 141 approved pilot school.

2. Possess a Commercial Pilot's certificate with Instrument and a Multi-Engine Aircraft ratings.

3. Possess a 2.75 overall grade point average on a 4.0 scale.

The SIUC Internship Selection Committee (composed of Aviation Management and Flight faculty members) ranks applicants based on academic performance, personal character, and applicant interviews. Successful candidates attend the week-long short internship at the United Airlines 
Training Center in Denver, Colorado. At the conclusion of the short internship all participants are evaluated and ranked by United Airlines for participation in the "United Airlines Occupational Internship," or "Long Internship."

The long internship consists of being assigned to one of several locations in the United Airlines system for a semester long (16 week) internship. These locations include the Flight Training Center in Denver, Colorado; the World Headquarters in Elk Grove Village, Illinois; and the Chicago Chief Pilot/Domicile office at Chicago-O'Hare International Airport. Students are assigned to a supervisor in a specific area of the airline (Flight Safety, Flight Dispatch, etc.). Interns perform duties as prescribed by their supervisor, they are also given access to flight simulators, they are involved in facility tours, and they take part in other industry related learning experiences. Dependent on flight simulator and class availability, some students earn a Flight Engineer Certificate during the internship.

Once a student completes the long internship and graduates with a B.S. degree in AVM from SIUC, he or she is eligible for a flight officer employment interview at United Airlines assuming minimum qualifications for flight officer employment are met. Those students not selected for the long internship, but successfully completed the short internship, were eligible for a flight officer employment interview through January 1992, upon attaining 1000 hours PIC (Pilot in Command) time and their B.S. degree in AVM. However, this part of the agreement was suspended by United Airlines due to poor flight officer interview results.

\section{LTTERATURE REVIEW}

Due to the recent emergence of airline flight operations internships, there is a limited amount of material in aviationrelated refereed journals on this subject. There is information contained in non-refereed sources such as internal airline documents and in commercial publications. This includes information of a general nature written about aviation internships, which has some application to airline internships.

The University Aviation Association (UAA) reports that "the civil pilot training (CPT) program of WWII serves as a foundation for partnerships between colleges and the aviation industry" (Kiteley, 1997, p. 1). Kiteley further states that internships and co-operative education programs (co-ops) are just one form of partnership between universities or colleges and airlines. Other types of partnerships with the airlines can include internships for faculty; service on advisory committees; airlines as sources of guest lecturers/adjunct faculty; and airlines as hosts for field trips to various airline facility locations.

But what about the need or rationale for aviation internships in general? The article "Is the Pilot Shortage Coming?" states:

As airline hirings hit record levels and traditional pilot pools dry up, corporate flight departments may have to make changes in order to keep and attract experienced, quality aviators...One of the keys for bridging the experience gap among young pilots is to develop closer cooperation between industry and schools, including establishing internship and work/educational cooperatives. (Bradley, 1997, p. 80)

With regard to aviation-related internships and co-ops, a UAA sponsored study (Schukert, 1993) reported that 31 UAA member institutions participated in over 60 aviation-related co-ops within their non-engineering aviation degrees. The single employer reported to use the aviation-related co-op students most often was the federal government.

The role of co-ops and internships in aviation in general has been addressed by several authors. For example:

The success and popularity of co-op is largely attributable to the fact that all three players benefit. In addition to increasing graduate placement, schools become privy to the public and private sector needs that their curricula should address. Employers gain access to committed, knowledgeable, temporary, and low-cost help, plus an opportunity to groom full time employees. The participating students get a unique opportunity to experience the real world in their chosen profession. Co-op programs usually provide pay and/or academic credit, and students gain a "foot in the door" with a familiar post-graduate employment prospect. More specifically, aviation employers can look forward to the following benefits of starting an intern program: highly motivated and enthusiastic employees; short term commitment; meeting immediate staffing needs; providing a diverse population; freeing professional staff; and facilitating entry-level recruitment. (Kitely, 1997, pp. 1-3) 
An article in the November 1996 issue of Flight Training notes an important rationale for an aviation internship from a student's perspective:

Simply stated, an internship or cooperative education program (co-op) is an opportunity for a college student to combine traditional on-campus academic learning with professional work experience in a chosen field. These programs allow students in a large number of collegiate aviation programs to bridge the gap between the classroom and the real world. (Phillips, p. 44)

With regard to airline internships specifically, an article in the October 1991 Collegiate Aviation Review reported that three airlines; United, Northwest and Eastern had a total of six university or community college "partners" including three airline-university intern agreements (NewMyer). It was noted that these partnerships were a response to "...the airline industry's search for an answer to the need for qualified, quality pilots." (NewMyer, p. 16)

A more recent article titled "Internships and Co-ops: Collegiate Programs That Can Make Your Aviation Career Take Off" discusses airline internships at United, Delta, TWA, USAir, and FEDEX. This article mentions numerous benefits of such internships to students, such as (1) being hired full time at United Airlines and FEDEX, (2) potential for being hired at Delta, (3) free simulator time, (4) some travel benefits, and (5) jump seat privileges for interns (Phillips, 1996).

One of the strongest statements in support of airline internships, which also provides an interesting corporate philosophy, is the opening statement from the "Southwest Airlines Internship Program Guidelines":

Southwest Airlines recognizes the importance and benefits of an official, company-wide internship program. By having young, talented and educated people from the aviation community come work for us, Southwest will be more efficient and productive than ever. In return, the interns will gain hands-on experience in the day to day operations of an airline. (Self, 1996, p. 1)

In general, the available literature points out the benefits of aviation and airline internships to both the airline and the student. The literature also contains some descriptive material about the airline flight operations internships, with the mention of such programs at five major airlines. However, the literature which was reviewed contained no industry-wide comprehensive information about flight operations internships.

\section{METHODOLOGY}

\section{Survey Participants}

Survey participants included all 110 students of the SIUC aviation program who participated in the United AirlinesSIUC long internship through August 1997.

\section{Survey Instrument Design}

The survey instrument was a mail-in questionnaire. The instrument was composed of six sections and designed to collect two types of information. First, it collected data related to the respondent's personal and professional characteristics. For example, Federal Aviation Administration (FAA) Aeronautical Certificates possessed, flight time, level of education, etc. The second type of data collected is attitudinal in nature. Using a Likert-type scale, attitudes toward the internship experience, classes taught at SIUC, and other relevant topics were collected. The Likert-type scale was used to allow respondents to indicate the extent to which they agreed or disagreed with a statement. The Likert-type scale was selected because of its simplicity and ease of use. Attitudes were assessed along a 5-point scale. The points ranged from 1 to 5 . The scoring of statements was dependent upon the particular scale. For example, Section IV of the survey asks respondents to rate the helpfulness of aviation classes taught at SIUC. A high response (5) represents the highest degree of helpfulness, while a low response (1) represents little helpfulness.

\section{Research Design}

The survey instrument was mailed to all 110 participants in the United-SIUC internship program. The Department of Aviation Management and Flight in conjunction with the SIUC Alumni Association developed a comprehensive list of program alumni addresses. Three mailings were conducted resulting in 78 responses, a return rate of $71 \%$. A $71 \%$ response rate represents an acceptable sample. McMillan and Schumaker (1989) discuss questionnaire follow-ups and the impact they have on response rates:

The initial mailing of the letter of transmittal, questionnaire, and stamped return-addressed envelope will usually result in a response rate of from forty to sixty percent-that is, forty to sixty percent of the sample will typically return the questionnaires. The first follow-up correspondence usually brings ten to twenty percent more returns, and a second follow-up will add another five to ten 
percent to the return rate. If researchers can obtain a total return of seventy percent or better, they are doing very well. In many studies the return rate is closer to fifty or sixty percent. (p. 295)

Responses were collapsed and analyzed using a descriptive methodology. Comparative percentages were used to represent "Overall Characteristics of Respondents", "Characteristics of Respondents Not Hired by United," and "Characteristics of Respondents Hired by United."

Overall Characteristics of Respondents

There were a total of 78 responses to the questionnaire. Of these, 64 (82\%) were male and 11 (14\%) were female. Three respondents did not indicate gender (see Table 1).

Table 1

Gender Breakdown (Overall)

\begin{tabular}{lcc}
\hline Sex & No. Responding & Percent Response \\
\hline Male & 64 & $82 \%$ \\
Females & 11 & $14 \%$ \\
\hline
\end{tabular}

*Three respondents did not identify gender

As indicated earlier, 78 former United Airlines interns from SIUC responded to this questionnaire. All 78 earned B.S. degrees AVM (see Table 2) and 64 (82\%) of the 78 also earned the A.A.S. degree in AF from SIUC.

Table 2

Degrees Earned by Interns

\begin{tabular}{lcc}
\hline Degree & No. Responding & Percent Response \\
\hline BS AVM & 78 & $100 \%$ \\
AAS AF & 64 & $82 \%$ \\
\hline
\end{tabular}

As noted in Figure 1, 13 of the respondents (17\%) graduated in the 1980's while the remaining $65(83 \%)$ graduated in the 1990 's.

\section{Interns by Graduation Date}

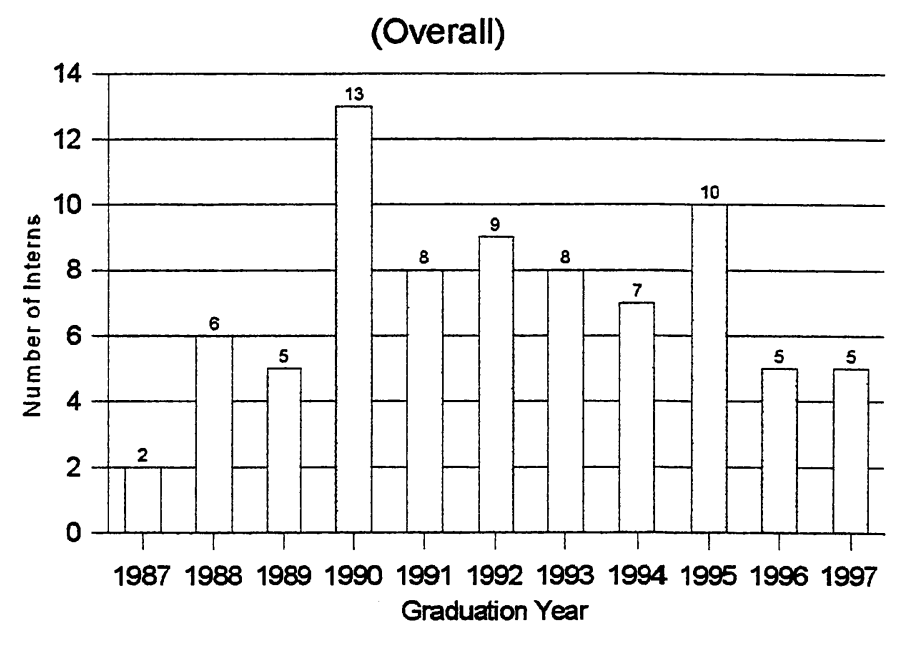

Figure 1. Interns by Graduation Date

In terms of the employment sector of the respondents (see Table 3), 41 (53\%) work for major airlines (those earning $\$ 1.0$ billion or more per year in gross annual revenues). Another 16 (20\%) work for regional airlines (those earning less than $\$ 1.0$ billion per year in gross annual revenues) while eight are flight instructors (10\%) and seven (9\%) work for corporate flight departments. Of the last six, three (4\%) work in other sectors of aviation and three are employed in a nonaviation field (4\%), one of which did not report their employment sector.

\section{Table 3}

Employment Sector

\begin{tabular}{lrc}
\hline Degree & No. Responding & Percent Response \\
\hline Major & 41 & $53 \%$ \\
Regional & 16 & $20 \%$ \\
Flight Instructor & 8 & $10 \%$ \\
Corporate & 7 & $9 \%$ \\
Other & 3 & $4 \%$ \\
Non-Aviation/NR & 3 & $4 \%$ \\
\hline Total & 78 & $100 \%$
\end{tabular}

When this information is broken down by employer (see Table 4), United Airlines is the top employer with 36 (46\%) 
respondents indicating that airline as their employer. The next largest employers reported were the regional carriers Mesaba Airlines employing four respondents (5\%) and Continental Express employing three respondents (4\%).

\section{Table 4}

Top Three Employers of United Interns

\begin{tabular}{lll}
\hline Rating & Airline & Number \\
\hline 1 & United Airlines & 36 \\
2 & Mesaba Airlines & 4 \\
3 & Continental Express & 3 \\
\hline
\end{tabular}

Federal Aviation Administration certification (see Table 5) is another indicator of respondent' quality. A total of 71 of the 78 respondents (91\%) were Certified Flight Instructors (CFI's). In addition, a total of 41 (53\%) held Air Transport Pilot Certificates; 64 (82\%) held Commercial Pilot Certificates; while 47 (60\%) held Flight Engineer Certificates.

\section{Table 5}

Certificates Possessed by Interns

\begin{tabular}{lcl}
\hline Certificate & No. Responding & $\begin{array}{l}\text { Percent } \\
\text { Response }\end{array}$ \\
\hline CFI & 71 & $91 \%$ \\
ATP & 41 & $53 \%$ \\
COMM & 64 & $82 \%$ \\
FE & 47 & $60 \%$ \\
\hline
\end{tabular}

\section{Characteristics of Respondents Not Hired by United}

\section{Airlines}

There were a total of 42 respondents who indicated that they had not been hired by United Airlines. Of these, 35 (83\%) were male and $6(14 \%)$ were female. One respondent did not indicate gender (see Table 6).

\section{Table 6}

Gender Breakdown

\begin{tabular}{lcl}
\hline Sex & No. Responding & Percent Response \\
\hline Males & 35 & $83 \%$ \\
Females & 6 & $14 \%$ \\
\hline
\end{tabular}

*One response did not identify gender
Of the 42 respondents not hired by United, all hold the B.S. degree in AVM with 37 (83\%) of them holding A.A.S. degrees in $\mathrm{AF}$ as well (see Table 7).

Table 7

Degree Breakdown

\begin{tabular}{lrl}
\hline Degree & No. Responding & Percent Response \\
\hline BS in AVM & 42 & $100 \%$ \\
AAS in AF & 37 & $88 \%$ \\
\hline
\end{tabular}

In addition, 3 of the 42 graduated from SIUC in the 1980's while the other $39(93 \%)$ graduated in the 1990 's. A total of $20(48 \%)$ of these graduated in the years 1995 to 1997 (see Table 8).

\section{Table 8}

Interns by Graduation Date - Overall and Not Hired by United Airlines

\begin{tabular}{lccc}
\hline Year & $\begin{array}{c}\text { Overall } \\
\text { Intems }\end{array}$ & $\begin{array}{c}\text { Not Hired by } \\
\text { United Airlines }\end{array}$ & $\begin{array}{c}\% \text { Not Hired by } \\
\text { United Airlines }\end{array}$ \\
\hline 1987 & 2 & 0 & $0 \%$ \\
1988 & 6 & 1 & $17 \%$ \\
1989 & 5 & 2 & $40 \%$ \\
1990 & 13 & 2 & $15 \%$ \\
1991 & 8 & 2 & $25 \%$ \\
1992 & 9 & 5 & $56 \%$ \\
1993 & 8 & 4 & $50 \%$ \\
1994 & 7 & 6 & $86 \%$ \\
1995 & 10 & 10 & $100 \%$ \\
1996 & 5 & 5 & $100 \%$ \\
1997 & 5 & 5 & $100 \%$ \\
\hline Total & 78 & 42 &
\end{tabular}

In terms of FAA certification, 40 of the respondents (95\%) held CFI's; 22 held Air Transport Pilot Certificates (52\%); 35 held Commercial Pilot Certificates (83\%); and 13 held Flight Engineer Certificates (31\%) (see Table 9). 
Table 9

Flight Certificate Breakdown

\begin{tabular}{lcl}
\hline Certificate & No. Responding & $\begin{array}{l}\text { Percent } \\
\text { Response }\end{array}$ \\
\hline CFI & 40 & $95 \%$ \\
ATP & 22 & $52 \%$ \\
Commercial & 35 & $83 \%$ \\
Flight Engineer & 13 & $31 \%$ \\
\hline
\end{tabular}

With regard to the employment sector (see Table 10) of the respondents not hired by United Airlines, 5 (11\%) work for a major U.S. airline; 16 (38\%) work for regional airlines, 8 (19\%) work as flight instructors; another 7 (17\%) work in the corporate sector, 3 (7\%) work in other sectors of the aviation industry; 2 (5\%) work in non-aviation related fields; and 1 (2\%) did not report employment sector. Of the major airlines employing former United interns, two (5\%) are with United Parcel Service Airlines; one (2\%) is with Trans World Airlines; one is with Northwest Airlines; and one (2\%) is with Mexicana Airlines, a foreign carrier.

Table 10

Employment Sector Breakdown

\begin{tabular}{lcc}
\hline Degree & No. Responding & Percent Response \\
\hline Major/Int'l & 5 & $12 \%$ \\
Regional & 16 & $38 \%$ \\
Flight Instructor & 8 & $19 \%$ \\
Corporate & 7 & $17 \%$ \\
Other & 3 & $7 \%$ \\
Non-Aviation & 2 & $5 \%$ \\
N/R & 1 & $2 \%$ \\
\hline Total & 42 & $100 \%$
\end{tabular}

Employment in the regional airline sector was reported by respondents as follows: four with Mesaba/Northwest Airlink; three with Continental Express, two with Great Lakes Aviation; two with Trans States Airlines/Trans World Express; two with West Air/United Express; two with Skyway Airlines; and one with Atlantic Coast Airlines/United Express.

Respondents reporting Flight Instruction as their present employment sector were, by a large, typically employed by Fixed Base Operators (FBO's). One exception was a CFI employed by SIUC. The remaining seven were employed by a variety of FBO's. One FBO, Kenosha Aero employed two of the respondents, the following list of FBO's employed one respondent each: Justice Aviation; Windy City Flyers; The Flight Center at Service Aviation; North Western Aviation; Ocean Aire Aviation; and Lumanair.

Employment within the "Corporate" sector was reported with one respondent employed in each of the following corporate flight departments: Household International Finance; Jet Air Inc.; Midwest Aviation Services; Cooper Tire; Southern Electric/Lakin Law Firm; McNeely Charter Service; and Sunstrand Aerospace.

Within the "Other" category reported by respondents are two Federal Aviation Regulation Part 135 Air Taxi Operators: St. Charles Flying Service and Lake Mead Air, employing one respondent each. Also reported within this category is one respondent working at an FBO; two respondents working nonaviation retail sales positions; and one respondent did not report a sector of employment.

The survey instrument also asked all respondents not hired by United Airlines what their perceptions were for not being hired:

- A total of $18(43 \%)$ of the respondents indicated that they strongly agreed or agreed with the statement: "Do you believe you were qualified for employment?" A total of 22 respondents (52\%) did not indicate an answer to this question. One (2\%) responded neutrally to this question and one strongly disagreed with it.

- A total of 12 respondents (29\%) indicated that they strongly agreed or agreed that the interview at United Airlines was extremely competitive with many qualified applicants for few positions. A total of 24 respondents (57\%) did not respond to this particular question while 1 (2\%) was neutral and 5 (12\%) either disagreed or strongly disagreed.

- $\quad$ Nine respondents $(21 \%)$ indicated that they strongly agreed or agreed that they did not have enough flight time or other experience for United Airlines. A total of 24 respondents (57\%) did not respond to this question. Another four (10\%) each were either neutral, disagreed or strongly disagreed with this question.

- A total of 16 respondents (38\%) disagreed or strongly disagreed that "Your lack of currency on aviation-related subjects/issues” was a reason for 
not being hired by United Airlines. A total of 22 respondents $(52 \%)$ did not respond to this question. Two respondents $(5 \%)$ were neutral; one $(2 \%)$ disagreed; and one (2\%) strongly disagreed.

- A total of 16 respondents (38\%) disagreed or strongly disagreed with the statement that "You believe the interview questions were not clear" was a reason for non-selection by United Airlines. Twenty-one respondents (50\%) did not respond to this question. Two respondents (5\%) agreed and three (7\%) were neutral.

A total of 18 respondents (43\%) disagreed or strongly disagreed that poor preparation was a reason for not being hired by United Airlines. Three (7\%) agreed with this statement and 21 (50\%) did not respond to this question.

- A total of 15 respondents (36\%) disagreed or strongly disagreed with the statement "The interview was not what you expected." A total of four respondents (10\%) strongly agreed or agreed with this statement and one (2\%) was neutral. A total of $22(52 \%)$ did not respond to this question.

A total of 11 respondents (26\%) disagreed or strongly disagreed that there was poor interaction with the person conducting the interview. A total of five respondents (12\%) strongly agreed or agreed with this statement and four (10\%) were neutral. Twenty-two (52\%) did not respond to this question.

\section{Characteristics of Interns Hired by United Airlines}

A total of 36 respondents indicated that they were hired by United Airlines. Of those 36 respondents, 5 (14\%) are female, $29(81 \%)$ are male and $2(5 \%)$ did not identify their gender (see Table11).

Table 11

Gender Breakdown

\begin{tabular}{lcl}
\hline Sex & No. Responding & Percent Response \\
\hline Males & 29 & $81 \%$ \\
Females & 5 & $14 \%$ \\
\hline
\end{tabular}

*Two respondents did not identify gender
Of the 36 respondents hired by United Airlines, all 36 (100\%) hold the B.S. in AVM while 27 (75\%) hold the A.A.S. in AF (see Table 12).

Table 12

Degree Breakdown

\begin{tabular}{lcl}
\hline Degree & No. Responding & Percent Response \\
\hline $\mathrm{BS}$ in AVM & 36 & $100 \%$ \\
$\mathrm{AAS}$ in AF & 27 & $75 \%$ \\
\hline
\end{tabular}

In addition, a total of $11(31 \%)$ of those hired by United Airlines graduated from SIUC in 1990, while another 10 (28\%) graduated prior to 1990 (see Figure 2). Also, it can be seen that the reported hiring by United Airlines tapers off among respondents to zero in 1995, 1996, and 1997. This reflects the fact that, even though the internship program gives a significant advantage to flight officer applicants in terms of getting an interview, the results are not usually immediate.

\section{Interns by Graduation Date}

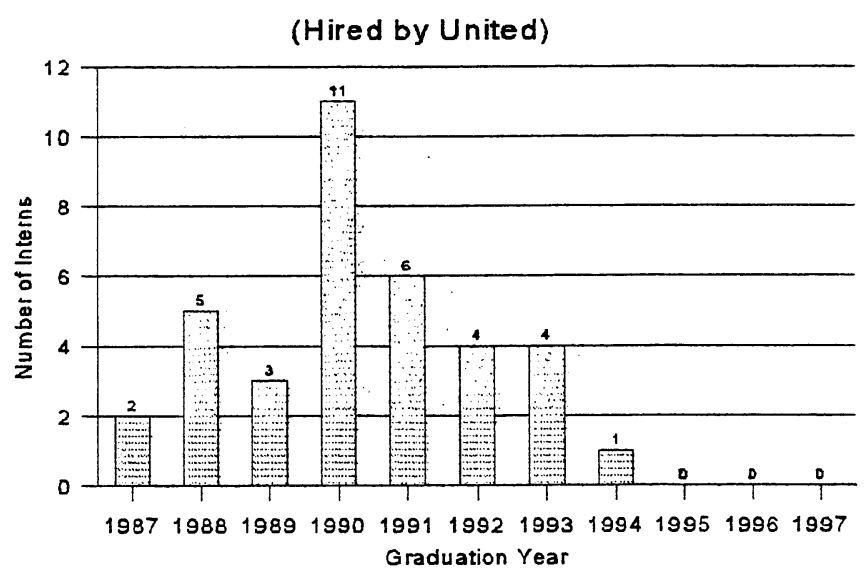

Figure 2. Interns by Graduation Date 
In terms of certificates held, Table 13 shows that interns hired by United Airlines tended to have significant certification. For example, 32 of the 36 (89\%) held the Flight Engineer Certificate at the time of hire. By comparison, $31 \%$ of those not hired by United Airlines reported having this Certificate. In addition, the interns hired by United Airlines held: Flight Instructor Certificates (83\%), the Commercial Pilot Certificate (83\%) and the Air Transport Pilot Certificate (58\%).

Table 13

Flight Certificate Breakdown

\begin{tabular}{lcl}
\hline Certificate & No. Responding & $\begin{array}{l}\text { Percent } \\
\text { Response }\end{array}$ \\
\hline CFI & 30 & $83 \%$ \\
ATP & 21 & $58 \%$ \\
Commercial & 30 & $83 \%$ \\
Flight Engineer & 32 & $89 \%$ \\
\hline
\end{tabular}

Additional flight qualifications held (see Table 14) by interns hired by United Airlines at the time of hire included an average of 1,467 of PIC flight time. This statistic ranged from a reported low of 250 (actually below United Airline's hiring requirements at the time) to a high of 3,915. In addition, respondents hired by United Airlines held an average of 722 hours of multi-engine flight time, with a reported range of 11 (right at the minimum needed for a FAA multi-engine rating) to 4,000 flight hours. Finally, respondents hired by United Airlines reported an average of 481 hours of turbine flight time. This statistic ranged from a reported low of zero to a high of 2,732 hours of turbine flight experience.

Table 14

Flight Time at Hiring Breakdown for All Hired by United Airlines (Hours)

\begin{tabular}{lrrrr}
\hline Type & Total & Avg. & Lowest & Highest \\
\hline PIC & 51339 & 1467.0 & 250 & 3915 \\
Multi & 25257 & 722.0 & 11 & 4000 \\
Turbine & 16844 & 481.0 & 0 & 2732
\end{tabular}

Crew-based flight experience is another characteristic reported by respondents. A total of 17 of the interns hired by United Airlines, including 2 females and 15 males, reported prior crew experience before being hired by United. This amounts to $47 \%$ of the interns hired by United Airlines (see Table 15).

Table 15

Interns Hired with Previous Crew Experience

\begin{tabular}{lcl}
\hline Gender & Total & Percent \\
\hline Male & 15 & $54 \%$ \\
Female & 2 & $25 \%$ \\
\hline Total & 17 &
\end{tabular}

This crew experience was reportedly earned primarily in the corporate flight department (59\%) or regional airline (41\%) sectors of the industry, with some respondents reporting more than one type of previous crew experience (see Table 16).

Table 16

Type of Previous Crew Experience

\begin{tabular}{lcl}
\hline Experience & No. Responding & Percent Response \\
\hline Corporate & 10 & $59 \%$ \\
Regional & 7 & $41 \%$ \\
Military & 1 & $6 \%$ \\
Other & 4 & $24 \%$ \\
\hline
\end{tabular}

*Some had more than one type of previous experience

\section{Female/Male Flight Time Characteristics of} Respondents Hired by United Airlines

Five respondents employed by United as flight officers were female (14\%) and two respondents did not identify their gender (5\%). The average PIC flight time reported by female respondents at time of hiring was 1,320 hours. Female respondents also averaged 587 hours of multi-engine flight time and an average of $\mathbf{4 4 0}$ hours turbine flight time (see Table 17).

\section{Table 17}

Breakdown of Flight Time at Hiring for Females (Hours)

\begin{tabular}{lrrcc}
\hline Type & Total & Avg. & Highest & Lowest \\
\hline PIC & 6,600 & 1,320 & 2,300 & 250 \\
Multi & 2,935 & 587 & 1,700 & 20 \\
Turbine & 2,200 & 440 & 1,500 & 0 \\
\hline
\end{tabular}

The average PIC flight time reported by male respondents at time of hiring was 1,541 hours. Male respondents also 
averaged 793 hours of multi-engine flight time and an average of 523 hours turbine flight time. Forty percent of female respondents possessed previous flight crew experience. Fiftytwo percent of male respondents possessed previous flight crew experience (see Table 18).

\section{Table 18}

Breakdown of Flight Time at Hiring for Males (Hours)

\begin{tabular}{llrrc}
\hline Type & Total & Avg. & Highest & Lowest \\
\hline PIC & 43,139 & 1,541 & 3,915 & 300 \\
Multi & 22,202 & 793 & 4,000 & 11 \\
Turbine & 14,644 & 523 & 2,732 & 0 \\
\hline
\end{tabular}

\section{CONCLUSIONS}

An overall review of survey data reflects that $82 \%$ of the respondents were male; all 78 earned a B.S. in AVM; $83 \%$ graduated in the 1990 's; $49 \%$ work for major airlines; with United Airlines employing $46 \%$. When it comes to flight qualifications $91 \%$ of the respondents were CFI's; $53 \%$ were Air Transport Pilots; $82 \%$ were Commercial Pilots; and $60 \%$ were Flight Engineers. It can therefore be concluded that male AVM graduates holding advanced flight certification are provided, by the United Airlines-SIUC internship program, with a pathway to professional pilot careers.

A profile of respondents not hired by United Airlines would indicate the following characteristics: $83 \%$ were male; all 42 possessed a B.S. degree in AVM; $93 \%$ graduated in the 1990's; 95\% were CFI's; $31 \%$ were Air Transport Pilots; $83 \%$ were Commercial Pilots; and 52\% were Flight Engineers.

Of those not hired by United Airlines, $12 \%$ work for other major airlines. The largest segment of respondents $(38 \%)$ not hired by United Airlines work in the regional airline sector. Nineteen percent of these respondents work as flight instructors; $17 \%$ work in the corporate sector; and $7 \%$ work in other sectors of the aviation industry.

Of all 42 respondents not being hired by United Airlines, only $5 \%$ do not work in the aviation industry. One respondent (2\%) did not indicate employment sector and no assumption was made as to whether or not he or she was employed in an aviation sector.

Those respondents not being hired by United Airlines had the following comments regarding their respective employment opportunity: $43 \%$ believed they were qualified; $29 \%$ indicated that the interview process was extremely competitive; $21 \%$ indicated that they did not have enough flight time; $38 \%$ did not believe they were deficient in aviation-related subjects/issues; $38 \%$ believed that the interview questions were clear; $43 \%$ felt prepared for the interview; $36 \%$ felt the interview was what they had expected it to be; $26 \%$ indicated that poor interaction with the interviewer was not an issue.

The responses to these questions would indicate that: respondents did possess the requisite qualifications; employment opportunities with United Airlines are very competitive; adequate flight experience (flight time) is a major qualifier; respondents felt up to date and conversant in aviation-related topics; questions asked during the interview were easily understood; respondents were prepared for the interview; the interview met expectations; and respondents were able to develop a rapport with the interviewer. This data would indicate that "flight time" and "competition" were perceived as deciding factors in not being hired by United Airlines.

Survey data indicates that the majority of respondents (29) employed as flight officers by United Airlines are male (81\%). This percentage is not surprising, as 64 of the 78 respondents (82\%) were male. Eleven respondents (14\%) hired by United Airlines were female. Three respondents (4\%) did not identify their gender. On average, female respondents possessed $14 \%$ less PIC flight time, $26 \%$ less multi-engine flight time and $16 \%$ less turbine flight time than male respondents at time of hiring. It should be noted that the average female respondent exceeded United Airline's minimum flight time hiring requirement. While the data collected reflect the characteristics of only five female respondents, it appears to indicate that United Airlines is making an effort to employ more female aviators.

A post-secondary education appears to be an important component of employment selection criteria; all interns held a B.S. degree in AVM, and the majority (75\%) also possessed an A.A.S. degree in AF. Respondents with advanced aeronautical certifications appear to have an advantage. Eighty-nine percent of the respondents hired by United Airlines possessed a Flight Engineer Certificate. The majority (83\%) of respondents hired by United Airlines also held CFI and Commercial Pilot Certificates. The average PIC flight time reported by respondents at time of hiring was 1,467 hours. Respondents also averaged 722 hours of multi-engine flight time and an average of 481 hours turbine flight time. A significant percentage of respondents $(47 \%)$ hired by United Airlines had served as pilots in a crew-based flight environment. This flight experience was attained primarily in corporate flight departments and regional airline sectors of the industry.

Based on the data acquired in this study, the qualification profile of the average respondent hired at United Airlines is as follows: 
1. Graduated between 1987 and 1994 .

2. Possess a bachelor's degree.

3. Holds an advanced flight certificate (CFI, ATP, Commercial, Flight Engineer).

4. Has achieved 1,467 PIC, 722 multiengine, and 481 turbine flight hours.

5. Has prior experience in a flight crew environment.

There is little doubt that the United Airlines-SIUC flight operations internship agreement met the general goals described by Spencer (1988). Since 36 of the respondents have been hired by United Airlines, it can be concluded that this program is a "source" of pilot candidates. In addition, since the minimum United Airlines flight officer hiring standards included a 350 hour pilot in command standard, the United Airlines-SIUC program provided candidates with 4 to 5 times (1,467 PIC hours) that standard. Also, all of these candidates had obtained a baccalaureate degree, which went beyond the requirements. Thus, it can be concluded that "high quality" candidates were provided to United Airlines.

In terms of providing qualified female and minority candidates, only female candidates were identified in the survey instrument. Those candidates had an average of 1,320 PIC hours upon being hired, again well in excess of the 350 PIC hour requirement. Finally, United Airlines not only took advantage of SIUC as a resource for pilot candidates, they have expanded the program to include 22 university and college aviation programs which send 30 to 35 interns per semester to United Airlines. This gives United Airlines the opportunity for an "early look" at over 100 of the "best of the best" college/university aviators each year.

\section{Recommendations for Further Research}

The literature review for this paper did not reveal any comprehensive review of the success of airline flight operations internship program. Therefore, an important recommendation to the airlines that operate such intern programs is to follow up with the participants of these programs and find out if the programs are meeting the goals of the airline and of the participants. In doing this research, it is also recommended that the survey instruments used in this future research use much more specific questions of the flight operations interns who are "not hired" by their airlines. In retrospect, the decision to not ask such specific questions in the current research placed a limitation on what could be said about the not hired group of respondents. Finally, it is strongly recommended that United Airlines, which has been in the flight operations internship business for over ten years, follow up on all of its interns from all of its participating universities. Such research might give some interesting insight about the influence of certain types of academic and flight-related preparation on the success of the interns once they reached the aviation industry, and United Airlines in particular..

David A. NewMyer holds a Doctor of Philosophy degree in Education Administration and Higher Education from Southern Illinois University, Carbondale; a Master of Arts in Metropolitan Studies from Drew University and a Master of Science in Transportation from Northwestern University. He is an Associate Professor and Chairperson, Department of Aviation Management and Flight at Southern Illinois University, Carbondale.

Jose R. Ruiz holds a Master of Aeronautical Science degree from Embry-Riddle Aeronautical University; a Bachelor of Science in Management/Human Resources from Park College. He is an Assistant Professor, Department of Aviation Management and Flight at Southern Illinois University, Carbondale.

D. Scott Worrells holds a Master of Aeronautical Science degree and a Bachelor of Science in Aviation Technology-Avionics from Embry-Riddle Aeronautical University. He is an Assistant Professor, Department of Aviation Management and Flight at Southern Illinois University, Carbondale. 


\section{REFERENCES}

Bradley, P. (1997, September). Is the Pilot Shortage Coming? Business and Commercial Aviation.

Kiteley, G. (1997, November 11). Auburn, AL: University Aviation Association.

Collins.

McMillan, J. H., \& Schumacher, S. (1989). Research in Education, A Conceptual Introduction ( ${ }^{\text {nd }}$ ed.). New York: HarperReview, 2(1), 15.

NewMyer, D. A. (1991, October). Status Report: An airline-university cooperative pilot career program. Collegiate Aviation

Phillips, W. (1996, November). Internships \& Co-ops: Collegiate Programs that can make your aviation career take off. Flight Training.

Schukert, M. A. (1993, May). Aviation Career Waypoints. Murfreesboro, TN: Middle Tennessee State University Aerospace Department.

Self, B. (1996, September 25). Southwest Airlines Internship Program Guidelines. Dallas, TX: Southwest Airlines.

Spencer, K. (1988, July 26). UAL Working Relationships with Aviation Colleges. Denver, CO: United Airlines.

Turney, M. A. (1997, September 22). Starting an Internship Program. Presentation to the Air Transport Association Operations and Safety Forum, Hilton Head, SC. 